\title{
Studies on Geocalycaceae (Hepaticae). XI. Supraspecific New Taxa and New Combinations in Chiloscyphus Corda for Australasia
}

\author{
John J. Engel
}

Department of Botany, The Field Museum, Chicago, Illinois 60605-2496, U.S.A.

\begin{abstract}
Aвstract. Chiloscyphus sect. Novae-zeelandii, sect. Semiteres, sect. Spiniferi, and sect. Hemispini are described as new. Chiloscyphus subg. Connati, subg. Microlophocolea, and subg. Cyanolophocolea are new combinations.
\end{abstract}

The following new taxa and new combinations are the result of a systematic study of the genus Chiloscyphus Corda in Australasia. The names are here published separately to make them immediately available for use.

1. Chiloscyphus sect. Novae-zeelandii Engel, sect. nov. TYPE: Jungermannia novaezeelandiae Lehmann \& Lindenberg, in Lehmann, Nov. Min. Cogn. Stirp. Pug. 6: 33. 1834.

Plantae dioicae, spicis masculis elongatis, bracteis quam foliis brevioribus, aliter velut in sect. Heterophylli.

Plants dioecious; branching of Frullania- and lateral-intercalary types or strictly lateral-intercalary; leaves with apex polymorphic, undivided and rounded to retuse to l-lobed to shallowly bilobed, at times all or a combination of these variants on 1 shoot, the leaf margins entire or armed with 1 or more teeth; underleaves bifid to $0.4-0.85$, the lamina margins 1-3 dentate-ciliate; androecia forming elongate spikes, the bracts smaller than leaves; gynoecia on main shoots or long leafy branches, never on short intercalary branches that lack leaves, never on terminal branches.

The section belongs in subgenus Lophocolea (Dumortier) Engel \& Schuster and is restricted to Australasia.

2. Chiloseyphus sect. Semiteres Engel, sect. nov. TYPE: Jungermannia semiteres Lehmann, Linnaea 4: 363. 1829.

Sectio Novae-zeelandii similis, gynoeciis interdum in ramis brevibus aphyllis latero-intercalaribus vel ramis terminalibus vel surculis principalibus, seta cellulis magis numerosis constructis, atque pariete interno capsulae non aequaliter incrassato differt.

Plants with branching terminal-lateral and lateral-intercalary or strictly lateral-intercalary; leaves undivided, the margins entire or dentate; underleaves 2-4-lobed at least to 0.5 , at times divided nearly to the base, the lamina margins on each side with a tooth or lobule. Gynoecia often on abbreviated lateral-intercalary branches lacking normal leaves, sometimes on terminal branches or main shoots.

The section belongs in subgenus Lophocolea, and is pan-south temperate in distribution.

3. Chiloscyphus subg. Connati (Lindenberg) Engel, comb. nov. Basionym: Plagiochila sect. V. Connatae Lindenberg, Species Hepathicarum XXIX. 1839. Lophocolea subg. Connatae (Lindenberg) Piippo, Ann. Bot. Fenn. 131: 165. 1985. TYPE: (see Piippo, 1985: 165): Chiloscyphus ciliolatus (Nees) Gottsche.

4. Chiloscyphus sect. Spiniferi Engel, sect. nov. TYPE: Chiloscyphus spiniferus (Hooker f. \& Taylor) Engel \& Schuster.

Plantae dioicae. Folia ad apicem subaeque bilobata. Cellulae foliorum amphigastriorum atque perianthiorum laeves sine protuberationibus, eaedem foliorum trigonis minutis. Amphigastria admodum magna, asteroidea, (4)6lobata, anguste utrinque connata.

Plants dioecious; leaves subequally bilobed; leaf, underleaf, and perianth cells smooth, without protuberances, the leaf cells with small trigones; underleaves exceedingly large, (4-)6-lobed, narrowly connate on both sides.

The section belongs in subgenus Connati and is restricted to New Zealand.

5. Chiloscyphus subg. Microlophocolea (Spruce) Engel, comb. et stat nov. Basionym: Lophocolea sect. Microlophocolea Spruce, Trans. \& Proc. Bot. Soc. Edinburgh 15: 426. 1885. Lophocolea sect. Microlophocolea (Spruce) Schiffner, in Engler \& Prantl, Natürl. Pflanzenfam. 1 (3): 92. 1893. Chiloscyphus sect. Microlophocolea (Spruce) Engel \& Schuster, Nova Hedwigia 39: 410. 1985 (1984). TYPE: Lophocolea liebmanniana Gottsche (lectotype, fide Grolle (1976)).

Novon 9: 22-24. 1999. 
6. Chiloseyphus sect. Hemispini Engel, sect. nov. TYPE: Chiloscyphus parvispinus Engel.

Plantae dioeciae, rami plerumque latero-intercalares interdum terminalo-laterales nunquam ventro-intercalares, folia pagina dorsali hispida ventrali laevi, lobi amphigastriorum integri vel parce (1-2) dentati.

Plants dioecious; branches mostly of lateral-intercalary type, less often of Frullania-type; leaves with dorsal surface hispid, the ventral surface of leaf uniformly smooth; underleaf lobes entire or at most with 1-2 teeth.

The section belongs to subgenus Microlophocolea and is restricted to Australasia.

\section{Chiloseyphus subg. Cyanolophocolea} (Schuster) Engel, comb. et stat nov. Basionym: Lophocolea sect. Cyanolophocolea Schuster, Hep. Anthoc. N. Amer. 4: 238. 1980. Chiloscyphus sect. Cyanolophocolea (Schuster) Engel \& Schuster, Nova Hedwigia 39: 409. 1985 (1984). TYPE: Lophocolea echinella Lindenberg \& Gottsche.

Subgenera and sections of Australasian Chiloscyphus may be distinguished by the following key.

\section{Synoptic Key to Australasian Subgenera and SECTIONS OF ChILOSCYPHUS}

la. Dorsal (and sometimes ventral) leaf surfaces armed with conspicuous sharp-pointed laminar and marginal processes formed of l-several cells; perianths armed on external (and often internal) surfaces with spinose cellular processes; antheridial stalk 1 -seriate.

2a. Leaf insertion extended to stem midline dorsally; gynoecia variable in position: acrogynous or cladogynous (the cladogynous lateralor ventral-intercalary, often or usually bearing vegetative leaves) ..... subg. Microlophocolea 3a. Ventral surface of leaf (suboptimal plants aside) with teeth; underleaf segments with opposing teeth or cilia, the abaxial surface of both segments and lamina often with scattered teeth; ventral-intercalary branches at least sometimes present ..... sect. Microlophocolea

3b. Ventral surface of leaf uniformly smooth; underleaf segments entire or at most with $1-2$ teeth, the teeth never regularly opposing, the abaxial surface of both segments and lamina smooth; ventral-intercalary branches lacking . . . . . . . . . . . sect. Hemispini

2b. Leaf insertion not extending to stem midline dorsally and delimiting a broad leaf free gutter 6-10 cells wide; gynoecia usually on abbreviated ventral-intercalary branches devoid of vegetative leaves ......... . . . . . . . . . subg. Cyanolophocolea lb. Leaf surfaces smooth or armed with thick-walled tubercles; perianths smooth, never armed with spinous processes; antheridial stalk 1- or 2-seriate.

4a. Aspect heteroscyphoid: subopposed leaves consistently and distinctly connate with adjacent, large, conspicuous and broad underleaves, thus each gyre bearing a single, continuous, leaf-complex; innermost capsule wall cells with semiannular bands often furcate and anastomosing to delimit fenestrae; antheridial stalks biseriate .... subg. Connati

5a. Leaf, underleaf, and perianth cells armed on both surfaces with prominent, central, dome-like, thick-walled tuberculae one each per cell ........ sect. Leucophylli

5b. Leaf and underleaf cells smooth, without protuberances of any sort.

6a. Underleaves 2-4-lobed or -lobulate, very broadly connate with lateral leaves, without conspicuous basal teeth; leaf cells with nodose trigones . . . . . . . . sect. Connati

6b. Underleaves (4-)6-lobed and with basal accessory teeth, narrowly connate with lateral leaves; leaf cells with small trigones .....

4b. Aspect chiloscyphoid: leaves usually clearly alternate, never conspicuously united with underleaves to form solitary ring-like units, the underleaves free or narrowly connate with leaves on one side (or if consistently narrowly connate on both sides, then connation obscure); innermost capsule wall cells with complete to incomplete to spurlike tangential thickenings that fail to fork or fork only sporadically and do not delimit fenestrae; antheridial stalks 1-seriate.

7a. Underleaves undivided and entire or at most bifid to 0.3 , the lamina margins at most with 1 tooth on each side; ventralintercalary branching common; leaves oriented subtransverse to subsuccubous, very rarely strongly succubous, the insertion strongly recurved at ventral end, distinctly inverted J-shaped subg. Notholophocolea

7b. Underleaves bifid to 0.4 or more, the lamina margins often with $2-3$ teeth or a laciniiform to lobuliform process on each side; ventral-intercalary branching rare or lacking; leaf orientation strongly succubous, the insertion not or hardly recurved at ventral end, at most weakly inverted J-shaped . . . . subg. Lophocolea 8a. Leaves fundamentally undivided, the apices on a single shoot at times variable and then rounded to 1- to 2-lobed, but never consistently bilobed.

9a. Gynoecial position variable, some to many on short, lateralintercalary branches lacking normal leaves (others on leading leafy shoots), at times on terminal branches; leaf apices 
broadly rounded to retuse or occasionally short bifid, not polymorphic, the shoots without a combination of undivided, 1- and 2-lobed leaves; perianth wings sporadic or lacking; inner layer of capsule wall cells with radial walls devoid of continuous sheets of pigmented thickening; seta 811 cells diam., with 26-30 epidermal cell rows; gemmae lacking ........ sect. Semiteres

9b. Gynoecia on main shoots or long leafy branches, never on short intercalary branches that lack vegetative leaves, never on terminal branches; leaf apices often polymorphic, the shoots with a combination of undivided, 1- and 2-lobed leaves; peri- anth wings rather common; inner layer of capsule wall cells with continuous sheets of pigmented thickening on vertical radial walls; seta (where known) 6-8 cells diam., with 17-21 epidermal cell rows; gemmae frequent ... sect. Novae-zeelandii 8b. Leaves fundamentally bilobed ...

. . . . . . . . . sect. Lophocolea

Acknowledgments. I thank Patricia Eckel and Gary Merrill for providing the Latin diagnoses.

\section{Literature Cited}

Grolle, R. 1976. Verzeichnis der Lebermoose Europas und benachbarter Gebiete. Feddes Repert. 87: 171-279.

Piippo, S. 1985. Bryophyte flora of the Huon Peninsula, Papua New Guinea. XII. Geocalycaceae (Hepaticae). Ann. Bot. Fenn. 131: 129-167, f. 1-19. 


\section{$2 \mathrm{BHL}$ Biodiversity Heritage Library}

Engel, John J. 1999. "Studies on Geocalycaceae (Hepaticae). XI. Supraspecific new taxa and new combinations in Chiloscyphus Corda for Australasia." Novon a journal of botanical nomenclature from the Missouri Botanical Garden 9, 22-24. https://doi.org/10.2307/3392110.

View This Item Online: $\underline{\text { https://www.biodiversitylibrary.org/item/14669 }}$

DOI: https://doi.org/10.2307/3392110

Permalink: https://www.biodiversitylibrary.org/partpdf/2995

\section{Holding Institution}

Missouri Botanical Garden, Peter H. Raven Library

\section{Sponsored by}

Missouri Botanical Garden

\section{Copyright \& Reuse}

Copyright Status: In copyright. Digitized with the permission of the rights holder.

License: http://creativecommons.org/licenses/by-nc-sa/3.0/

Rights: https://biodiversitylibrary.org/permissions

This document was created from content at the Biodiversity Heritage Library, the world's largest open access digital library for biodiversity literature and archives. Visit BHL at https://www.biodiversitylibrary.org. 